\title{
KIAI DAN KEMANDIRIAN EKONOMI PESANTREN
}

\author{
Mohammad Anas \\ Gresik \\ mohammadanas1204@gmail.com
}

\begin{abstract}
This is a field research that focuses on pesantren as the oldest and original educational institution in Indonesia and has successfully emerged as an independent educational institution. This success cannot be separated from the work and contribution of the kiai in organizing the pesantren. To unravel this theme, there are two formulations of problems that to be discussed, namely, (1) how is the kiai's role in establishing economic independence at the Mambaus Sholihin Islamic Boarding School, Gresik? and (2) what factors shape the economic independence of the Mambaus Sholihin Islamic Boarding School in Gresik? The method used in this study is a qualitative research method with two approaches, including: first, qualitative case studies which emphasize the subjective aspects of people's behavior. Second, symbolic interaction that seeks to understand human behavior from the subject's point of view. The results of this study conclude that the kiai's role in the economic activities of the pesantren is very significant, both because of internal and external factors in shaping the economic independence of the pesantren.
\end{abstract}

Keywords: Kiai's Gait, Independence, Islamic Boarding School

\begin{abstract}
Abstrak: Penelitian ini adalah penelitian lapangan yang akan mengurai tentang pesantren sebagai lembaga pendidikan tertua dan asli di Indonesia dan telah berhasil tampil sebagai lembaga pendidikan independen. Keberhasilan tersebut tidak lepas dari kiprah dan kontribusi kiai dalam mengorganisir pesantren. Untuk mengurai tema ini, ada dua rumusan masalah yang akan dibahas yaitu, (1) bagaimana kiprah kiai dalam membentuk kemandirian ekonomi di Pondok Pesantren Mambaus Sholihin, Gresik? dan (2) faktor apa yang membentuk kemandirian ekonomi di Pondok Pesantren Mambaus Sholihin Gresik. Adapun metode yang digunakan dalam penelitian ini adalah metode penelitian kualitatif dengan dua pendekatan, antara lain: pertama, kualitatif studi kasus yang lebih menekankan pada aspek subjektif dari perilaku orang. Kedua, interaksi simbolik yang berusaha memahami perilaku manusia dari sudut pandang subjek. Hasil penelitian ini menyimpulkan bahwa kiprah kiai dalam kegiatan perekonomian pesantren sangat signifikan baik karena faktor internal dan faktor eksternal dalam membentuk kemandirian ekonomi pesantren.
\end{abstract}

Kata Kunci: Kiprah Kiai, Kemandirian, Pesantren.

\section{Pendahuluan}

Pesantren adalah lembaga pendidikan tradisional yang lahir dan tumbuh berbarengan dengan datangnya Islam ke tanah Jawa. Dengan demikian, pesantren merupakan lembaga

\section{maliyate}

Jurnal Hukum Bisnis Islam

Volume 10, Nomor 01, Juni 2020

p-ISSN: 2088-4869/ e-ISSN: 2597-4351 
pendidikan tertua dan asli (indegenous) di masyarakat Indonesia. ${ }^{1}$ Sejak kehadirannya, pesantren telah berhasil tampil sebagai lembaga pendidikan yang tumbuh dan berkembang atas kemampuan sendiri dan tidak terkooptasi dari kepentingan-kepentingan eksternal pesantren.

Keberhasilan tersebut tidak dapat dilepaskan atas nilainilai kehidupan yang dipelihara dan ditanamkan kiai pengasuh pesantren kepada para santrinya. Salah satu nilai yang menjadi ciri khas pesantren dan sekaligus sangat mempengaruhi keberlangsungannya adalah kemandirian. Kemandirian merupakan sifat yang ditunjukkan untuk tidak menggantungkan diri kepada orang lain, sehingga pesantren sebagai sebuah komunitas tumbuh dan berkembang dengan mengandalkan kemampuan sendiri, tanpa tergoda oleh kepentingan-kepentingan oportunis dan kesenangan sesaat. ${ }^{2}$

Pada masa-masa awal kehadiran pesantren di masyarakat Indonesia pada awal 1990-an lembaga pendidikan ini didirikan kiai dengan mendapat sokongan penuh dari masyarakat. Masyarakat memiliki andil yang sangat besar bersama kiai dalam pendirian pesantren di kampung atau desanya. Mereka menyumbangkan aset (berupa tanah), bahan bangunan, bahan pangan dan sebagainya, sehingga sebuah pesantren dapat dengan mudah didirikan. Sokongan masyarakat tersebut terus berlanjut ketika pesantren telah berjalan, sehingga pesantren dapat eksis dalam putaran zaman hingga sekarang. Fenomena tersebut tidak terlepas dengan masih kuatnya nilai-nilai sosial keagamaan, gotong-royong, kebersamaan (guyub), yang tentunya sangat didukung oleh

1 Manfred Ziemik, Pesantren Dalam Perubahan Sosial, Terj. Butche B Soendjoyo (Jakarta: P3M, 1986).100, Bandingkan Kuntowijoyo, Paradigma Islam: Interpretasi untuk Aksi (Bandung: Mizan, 1990), 57. Periksa juga Nurcholish Madjid, Bilik-bilik Pesantren: Sebuah Potret Perjalanan (Jakarta: Paramadina 1997), 3.

2 Mohammad Muchlis Solichin, "Kemandirian Pesantren Di Era Reformasi," Nuansa Vol. 9 No.1 (n.d.). 
masih tingginya ketundukan dan penghormatan masyarakat

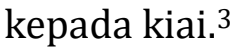

Namun demikian, pada masa sekarang sejalan dengan derasnya arus modernisasi di semua aspek kehidupan masyarakat yang mengendurkan nilai-nilai atau pandangan hidup di atas, dukungan dan sokongan penuh masyarakat kepada pesantren mengalami berbagai pergeseran. Arus modernisasi telah memberikan perubahan yang signifikan terhadap pandangan hidup masyarakat, dari kebersamaan (guyub), gotong royong, dan nilai-nilai spiritualitas ke arah pandangan hidup modern seperti sekularisme, materialisme, konsumerisme, hedonisme. Pandangan hidup modern di atas mengendurkan animo, dan sokongan masyarakat pada umumnya kepada pesantren. ${ }^{4}$

Kondisi di atas mengakibatkan banyak pesantren yang mengembangkan kekuatan ekonomi internal untuk tetap eksis dan membiayai penyelenggaraan pendidikannya. Oleh karena itu, tidak mengherankan ketika banyak pesantren yang mengembangkan kekuatan ekonomi dalam berbagai bentuk badan usaha baik itu berupa koperasi, bank perkreditan, pengelolaan pertanian, perkebunan, dan lain-lain. Sebagaimana pengembangan perekonomian pesantren di Pondok Pesantren Sidogiri, di mana mereka mempunyai banyak produk ekonomi, seperti produksi air minum santri, sarung, percetakan dan mempunyai koperasi-koperasi yang dibangun di daerahdaerah. ${ }^{5}$

Pengembangan ekonomi pesantren juga dilakukan oleh Pondok Pesantren Mambaus Sholihin yang terletak di desa Suci, kecamatan Manyar, kabupaten Gresik. Letaknya yang

3 Ibid.

4 Ibid.

5 Siti Nur Aini Hamzah, "Manajemen Pondok Pesantren Mengembangkan Kewirausahaan Agrobisnis: Studi Multi-Kasus Di Pondok Pesantren Mukmin Mandiri Sidoarjo Dan Pondok Pesantren Nurul Karomah Pamekasan Madura” (Tesis Universitas Islam Negeri Maulana Malik Ibrahim Malang, 2015). 
cukup strategis (tepat disebelah jalan utama) dan mudah dijangkau dari berbagai penjuru menjadikan pesantren ini cukup cepat perkembangannya. Tercatat pada tahun 2018, pesantren ini sudah mempunyai tujuh cabang yang tersebar di seluruh daerah di Indonesia dengan jumlah santri putra dan putri sekitar lima ribu lebih santri. ${ }^{6}$

Pondok Pesantren Mambaus Sholihin adalah pesantren memadukan antara sistem pendidikan pesantren salaf dengan sumber inspirasi Pondok Pesantren Langitan Tuban dan model pesantren modern dengan sumber inspirasi Pondok Pesantren Gontor di Ponorogo. Dalam tradisi salaf, pola pendidikan nonformal dan kurikulumnya diadopsi di pesantren ini. Sedangkan penguasaan bahasa Arab dan Inggris sebagai bahasa harian para santri dan sistem organisasi sosial kemasyarakatan yang berkembang di pesantren Mambaus Sholihin adalah terinspirasi dari Pesantren Gontor. Sebagai alumnus dari kedua pesantren tadi, tentunya hal ini yang sedari awal menginspirasi Kiai Masbuhin dalam mendesign dan menyusun sistem pembelajaran di pesantrennya. ${ }^{7}$

Perkembangan pesantren Mambaus Sholihin yang umurnya belum sampai setengah abad ini tidak terlepas dari keberkahan dari seorang guru. Pun demikian, upaya perkembangan pesantren juga tidak dilepaskan dari kiprah Kiai Masbuhin dalam membangun roda ekonomi di pesantren secara mandiri. Di antara kiparah beliau adalah dengan membangun Kreasi dan inovasi ekonomi pesantren yang telah

6 Cabang-cabang pondok pesantren Mambaus Sholohin di antaranya: (1) Pondok Pesantren Mambaus Sholohin pusat di Suci Manyar Gresik; (2) Pondok Pesantren Mambaus Sholohin Bendo Serengat di Blitar Gresik; (3) Pondok Pesantren Mambaus Sholohin Benjeng di Benjeng Gresik; (4) Pondok Pesantren Mambaus Sholohin Balung Panggang di Balung Panggang Gresik; (5) Pondok Pesantren Mambaus Sholohin Bali di Bali; (6) Pondok Pesantren Mambaus Sholohin Bintan di Bintan; (7) Pondok Pesantren Mambaus Sholohin Ambon di Ambon

Masbuhin Faqih (Pengasuh Pondok Pesantren Mambaus Sholihin), Wawancara, Gresik 27 Februari 2018.

7 Ibid. 
lama diinisiasi beliau dan sampai hari ini bisa dikatakan cukup berhasil. Beberapa produk ekonomi pesantren Mambaus Sholihin antara lain: Koperasi Pondok Pesantren (Kopontren), dengan omset perbulan sekira 25 juta sampai 30 juta. $^{8}$

Bertolak dari latarbelakang ini, maka penulis menetapkan beberapa masalah pokok penelitian dalam rumusan masalah sebagai berikut: Bagaimana kiprah kiai dalam membentuk kemandirian ekonomi di Pondok Pesantren Mambaus Sholihin Gresik? Begitu juga faktor apa yang membentuk kemandirian ekonomi di Pondok Pesantren Mambaus Sholihin Gresik?

\section{Relasi antara Kiai dan Pesantren}

Secara definitif, kata kiai memiliki ragam pemaknaan. Secara umum 'kiai' dimaknai sebagai penyebutan kepada seseorang yang dihormati yang memiliki ilmu keagamaan. Secara luas, terdapat ragam tafsir tentang kiai. Dalam percakapan di beberapa daerah, ajengan memiliki arti sinonim dengan kiai. ${ }^{9}$ Ajengan memiliki makna sebagai orang yang terkenal, yang kemudian diikuti dengan penjelasan "terutama guru agama Islam". Dalam penjelasan tersendiri mengenai arti kata 'kiai' memiliki beberapa pengertian, yaitu: (1) sebutan bagi alim ulama (cerdik pandai-agama Islam); (2) alim ulama, misalnya; (3) sebutan bagi guru ilmu gaib (dukun, dan lain sebagainya); (4) kepala distrik (sebutan di daerah); dan (5) sebutan bagi benda yang dianggap bertuah (di keraton-keraton, senjata, gamelan, dsb, disebut dengan 'kiai').10 Pemaknaan mengenai kata 'kiai' juga dapat diartikan sebagai seorang "ahli", yang berfokus pada bidang keagamaan. ${ }^{11}$

Dalam kehidupan masyarakat di Indonesia, kiai ditempatkan sebagai tokoh, yang karena dianggap memiliki

8 Dwi Iqbal Firdaus, Wawancara, Gresik, 12 Maret 2018.

9 Tim Pusat Bahasa Departemen Pendidikan Nasional, Kamus Besar Bahasa Indonesia (Jakarta: Gramedia Pustaka Utama, 2008).24

10 Ibid.767-768

11 Ibid.7 
kelebihan dalam hal ilmu pengetahuan agama dan kebijaksanaan, seringkali didatangi dan dimintai nasihat. Secara teknis, Zamakhsari Dhofier mengatakan bahwa seseorang bisa disebut kiai jika telah memiliki pesantren, walaupun tidak menutup kemungkinan, figur yang tidak memiliki pesantren tetap dapat disebut kiai, tergantung bagaimana karakter dan dinamikanya masing-masing. ${ }^{12}$

Dalam konteks di Indonesia, dan di dunia kebanyakan, al-Qur'an dan Hadis sebagai rujukan utama, pada kenyataannya hanya dimengerti oleh sebahagian kecil. Dalam kaitan ini, para ulama adalah rujukan umat; ulama memegang peran dan tugas kedakwahan yang diyakini sebagai kewajiban dalam jalan agama. Kiai, yang di sini merupakan penyebutan dari ulama, tak ubahnya adalah pemegang peran dan fungsi sosial yang penting dalam masyarakat beragama. Pemberontakan di Aceh dapat dijadikan salah satu contoh yang cukup jelas dalam kaitannya dengan ketundukan masyarakat terhadap para ulamanya di tengah pertentangan daerah tersebut dengan negara. Para ulama, yang diyakini sebagai para pewaris agama, merupakan satu pusat politik yang dapat menggerakkan dengan mudah warga setempat untuk mendukung atau melawan Pemerintah. ${ }^{13}$

Adanya kiai, sebahagian besar memiliki pesantren. Secara terminologis, pengertian pondok pesantren cukup banyak dikemukakan para ahli. Misalnya Zamakhsyari Dhofier mendefinisikan bahwa pondok pesantren adalah lembaga pendidikan tradisional Islam untuk mempelajari, memahami, menghayati dan mengamalkan ajaran Islam dengan menekankan pentingnya moral keagamaan sebagai pedoman perilaku sehari-hari.14 Sedangkan M. Ridlwan Nasir mendefinisikan bahwa pondok pesantren adalah lembaga

12 Zamakhsyari Dhofier, Tradisi Pesantren: Studi Tentang Pandangan Hidup Kyai (Jakarta: LP3ES, 1982).

13 Shane Joshua Barter, "Ulama, the State, and War," Contemporary Islam Vol.

5, No (2011): 20-26.

14 Dhofier, Tradisi Pesantren: Studi Tentang Pandangan Hidup Kyai.84 
keagamaan yang memberikan pendidikan dan pengajaran serta mengembangkan dan menyebarkan ilmu agama Islam. ${ }^{15}$

Adapun Mastuhu mendefinisikan pondok pesantren sebagai lembaga tradisional Islam untuk memahami, menghayati dan mengamalkan ajaran agama Islam (tafaqquh fi al-dīn) dengan menekankan pentingnya moral agama Islam sebagai pedoman hidup bermasyarakat sehari-hari. ${ }^{16}$ Sedangkan Arifin mendefinisikan pondok pesantren sebagai suatu lembaga pendidikan agama Islam yang tumbuh serta diakui oleh masyarakat sekitar, dengan sistem asrama (kampus) di mana menerima pendidikan agama melalui sistem pengajian atau madrasah yang sepenuhnya berada di bawah kedaulatan dari kepemimpinan (leadership) seorang atau beberapa orang kiai dengan ciri-ciri khas yang bersifat karismatik serta independen dalam segala hal. ${ }^{17}$

Kiai merupakan sebuah figur yang menjadi titik sentral dalam pesantren, dan fungsi kiai adalah sebagai pemimpin dalam pondok pesantren. Adapun fungsi kepemimpinan secara umum antara lain:

1. Fungsi instruksi. Dalam konteks ini, fungsi berlangsung dan bersifat komunikasi satu arah. Pemimpin sebagi pengambil keputusan berfungsi memerintahkan pelaksanaanya pada orang-orang yang dipimpin.

2. Fungsi konsultatif. Komunikasi ini berlangsung dan bersifat dua arah, meskipun pada pelaksanaannya tergantung pada pihak pemimpin.

3. Fungsi partisipatif. Fungsi ini tidak sekadar berlangsung dan bersifat dua arah, tetapi juga berwujud pelaksanaan hubungan manusia yang efektif antara pemimpin dengan dan sesama orang yang dipimpin. Dalam fungsi ini

15 M. Ridwan Nasir, Mencari Tipologi Format Pendidikan Ideal (Yogyakarta: Pustaka Pelajar, 2005).80

16 Mastuhu, Dinamika Sistem Pendidikan Pesantren: Suatu Kajian Tentang Unsur Dan Nilai Pendidikan Pesantren (Jakarta: INIS, 1994).6

17 H.M Arifin, Kapita Selekta Pendidikan: Islam Dan Umum (Jakarta: Bumi Aksara, 1995).240 
pemimpin berusaha mengaktifkan orang-orang yang dipimpinnya, baik dalam pengambilan keputusan maupun pelaksanaannya.

4. Fungsi delegatif. Fungsi ini dilaksanakan dengan memberikan pelimpahan wewenang membuat/ menetapkan keputusan, baik melalui persetujuan maupun tanpa persetujuan pemimpin.

5. Fungsi pengendalian; Fungsi ini cenderung bersifat komunikasi satu arah, meskipun tidak mustahil untuk dilakukan dengan cara kmunikasi dua arah. Fungsi pengendalian bermaksud bahwa kepememimpinan yang sukses/efektif mampu mengatur aktivitas anggotanya secara terarah dan dalam koordinasi yang efektif.

6. Fungsi teladan. Artinya, seorang kiai dijadikan model perilaku yang dapat diteladani pengikutnya. Ini peran besar yang harus dilakukan oleh kiai, yakni menjadi teladan bagi pengikutnya, baik warga pesantren maupun masyarakat umum secara luas. Keteledanan yang baik menjadi hal urgen yang harus dilakukan, agar pihak lain dapat meniru dan mengikuti jalan kebaikan yang telah dilakukan oleh kiai yang posisinya sebagai pimpinan pesantren.

Dalam konteks ini kiai adalah figur yang memberikan kontribusi signifikan dalam memperbaiki kehidupan masyarakat. Dalam upayanya mendirikan pesantren, kiai dianggap mampu mengeksplorasi nilai-nilai strategis dalam pengembangan masyarakat Indonesia. ${ }^{18}$ Dalam konteks kini, seorang kiai harus mempunyai wawasan, kebijaksanaan, terampil dalam ilmu agama, mampu memberikan teladan dan figur baik. Lebih jauh lagi, kiai lebih jauh lagi kiai di pondok pesantren biasanya dikaitkan dengan kekuasaan supranatural dan dianggap sebagai figur ulama adalah pewaris risalah kenabian, sehingga eksistensinya dianggap memiliki kedekatan hubungan dengan Tuhan. ${ }^{19}$ Dengan

18 Abd A'la, Pembaruan Pesantren (Yogyakarta: Pustaka Pesantren, 2006).57

19 Imron Arifin, Kepemimpinan Kyai: Kasus Pondok Pesantren Tebuireng (Malang: Kalimasada Press, 2003).45 
segala karakteristiknya, kepemimpinan kiai berperan penting dalam menjadikan pesantren sebagai institusi pendidikan yang selalu berkembang dan eksis mengikuti perkembangan teknologi dan memberikan bekal life skill untuk para santri.

\section{Pesantren sebagai Sentral Pertumbuhan Ekonomi Mikro}

Pesantren adalah lembaga pendidikan tradisional yang lahir dan tumbuh berbarengan dengan datangnya Islam ke tanah Jawa. Dengan demikian, pesantren adalah institusi pendidikan keagamaan asli dan tertua dalam masyarakat Indonesia. ${ }^{20}$ Semenjak kehadiran pesantren, ia telah sanggup tampil sebagai institusi pendidikan keagaaan yang tumbuh dan berkembang atas kemampuan sendiri dan tidak terkooptasi dari ragam kepentingan eksternal pesantren. Keberhasilan itu tidak dapat dilepaskan atas nilai-nilai hidup yang eksis dan diberikan kiai pada seluruh santrinya. Di antara nilai yang menjadi penciri pesantren dan yang sangat mempengaruhi keberlangsungannya adalah kemandirian.

Sebagai institusi pendidikan keagamaan tertua, pesantren berkembang dan tumbuh atas usaha mandiri masyarakat karena didorong adanya kebutuhan di antara mereka. Lafal pesantren berasal dari kata "pesantrian", yaitu kata imbuhan yang mengandung kata dasar santri, murid. ${ }^{21}$ Pun ada juga yang menyebutkan bahwa lafal santri berasal dari kata cantrik (bahasa Sansakerta), orang yang selalu mengikuti guru. Sementara itu, C.C. Berg berpendapat bahwa istilah tersebut berasal dari istilah shastri, yang dalam bahasa India berarti orang yang mengetahui ragam buku suci agama Hindu atau seorang sarjana ahli kitab suci agama Hindu. ${ }^{22}$

Terdapat tiga pilar utama yang mencirikan keberadaan pondok pesantren, antara lain: kiai, santri, dan pendidikan. Kiai adalah figur tertinggi yang menjadi pemimpin di pesantren.

20 Ziemik, Pesantren Dalam Perubahan Sosial, Terj. Butche B Soendjoyo.

21 Ibid. 15

22 A.S Karni, Etos Studi Kaum Santri: Wajah Baru Pendidikan Islam (Bandung: Mizan, 2009).15 
Adapun santri adalah mereka yang mengaji di pesantren, sebutan untuk murid-murid yang menempuh pendidikan secara umum. Pendidikan merupakan esensi keberadaan pesantren itu sendiri sebagai institusi pendidikan keagamaan yang terintegrasi. Pesantren mengembangkan, mengajarkan, sekaligus menerapkan ajaran dan ragam nilai agama dalam kehidupan para santri dan masyarakat secara umum. Kiai adalah figur sentral dalam kehidupan pesantren. ${ }^{23}$

Dalam hal ini, peran kiai tidak sekadar pemimpin pesantren, tetapi mereka juga guru sekaligus teladan perilaku baik bagi para santri dan elemen masyarakat lainnya di lingkungan pesantren. Ada beberapa ciri khas yang dimiliki pesantren sebagai lembaga pendidikan sekaligus lembaga sosial. Zamakhsyari Dhofir mcngajukan lima unsur yang melekat sebagi ciri-ciri khusus (karakteristik) pada diri pesantren yang meliputi; pondok, masjid, pengajaran kilabkitab Islam klasik, santri dan kiai. ${ }^{24}$

Oleh Karena itu Pondok pesantren bukan hanya terbatas dengan kegiatan-kegiatan pendidikan keagamaan semata melainkan mengembangkan diri menjadi suatu lembaga pengembangan masyarakat. dan Pondok Pesantren sejak semula merupakan ajang mempersiapkan kader masa depan melalui kelima unsur di atas. Namun saat ini sesuai dengan perkembangan zaman pesantren telah menempa dirinya dengan mengembangkan dirinya pada kegiatan-kegiatan pemberdayaan baik terhadap santri dan masyarakat seperti persoalan perckonomian, pengembangan lingkungan hidup dan Iain-lain sebagai wujud dari kemandirian pesantren baik dari segi keberadaannya sebagai lembaga mandiri maupun dalam menyelesaikan persoalan-persoalan dalam melaksanakan fungsinya. ${ }^{25}$ Dengan demikian maka pondok pesantren dari aspek fungsionalnya memiliki fungsi: ${ }^{26}$

23 Ibid.

24 Dhofier, Tradisi Pesantren: Studi Tentang Pandangan Hidup Kyai.

25 Moh Holis, "Pesantren Dan Pengembangan Perekonomian Di Pondok Pesantren Miftahul Ulum Panyepen, Palengaan, Pamekasan, Madura" (Tesis 
1. Pesantren sebagai lembaga pendidikan. Pada awalnya pendidikan di pesantren dimulai dari pengajian yang sederhana, mulai dari mengaji al-Qur'an di surau hingga pada akhimya berkembang menjadi lembaga pendidikan secara reguler oleh santri baik yang menetap atau santri kalong, atau masyarakat sekitar yang ingin mendalami ilmu agama.

2. Pesantren sebagai lembaga dakwah. Pesantren dikatakan sebagai lembaga dakwah mengingat kiprahnya dalam melakukan dakwah di kalangaan masyarakat, dalam arti melakukan suatu aktivitas menumbuhkan kesadaran dalam melaksanakan ajaran-ajaran agama secara konsekuen sebagai pemeluk agama Islam. Pada hakikatnya keberadaan pesantren di tengah masyarakat merupakan lembaga yang bertujuan menegakkan kalimat Allah.

3. Pesantren sebagai lembaga sosial-ekonomi. Lebih jauh lagi garapan pesantren tidak terbatas hanya di bidang sosialkeagamaan dan sosial-budaya, namun pesantren juga sudah masuk pada ranah kehidupan modern, dengan arti pesantren tidak hanya menggarap masalah-masalah ukhrawi saja akan tetapi aspek materi juga sudah dijangkaunya. Faktor terscbut tentunya merupakan paradigma baru mengingat para tokoh-tokoh pesantren kontemporer memandang bahwa pembaharuan dan pengembangan yang sesuai dengan tuntutan zaman harus

Universitas Islam Negeri Sunan Ampel Surabaya, 2008).34 Dalam bahasa yang berbeda sebagaimana disampaikan oleh Sirajul Arifin dan Muhammad Andik Izzuddin, bahwa pemberdayaan seperti ini dilakukan untuk menanggulangi kemiskinan. Konsep pengentasan kemiskinan mencakup pemberian akses kepada kelompok miskin, pemberdayaan untuk bisa mandiri, peningkatan kapasitas, dan perlindungan sosial. Strategi perluasan akses merupakan faktor urgen dalam pengentasan kemiskinan, karena biasanya warga miskin tak memiliki kekuatan untuk membuka akses yang diperlukan. Membuka akses akan menciptakan masyarakat mendapatkan kesempatan dalam pemenuhan kebutuhan dasar dan peningkatan kesejahteraan secara berkala. Lihat Sirajul Arifin dan M. Andik Izzuddin, "Ekonomi Lumbung dan Konstruksi Kebedayaan Petani Muslim Madiun”, Inferensi, Vol. 10, No. 1 (2016), 191.

26 Ibid. 
dilakukan seperti pengembangan bidang sosial-ekonomi dan teknologi.

Wujud nyata dari upaya pengembangan tersebut dapat direalisasikan melalui upaya peningkatan taraf hidup masyarakat ekonomi lemah pada tingkat yang lebih mapan. Demikian juga pengembangan ekonomi di dalam tubuh pesantren sendiri dengan arti pesantren bisa mampu menghidupi dirinya sendiri melalui program perekonomiannya, mengingat predikat "lembaga mandiri" yang disandangnya menuntut adanya kemandirian pesantren dalam berbagai aspek.

Pengembangan aspek perekonomian ini sebenamya merupakan langkah strategis mengingat ada sebagian pesantren yang sebenamya mampu menggarap bidang tersebut di samping juga mempunyai kekayaan internal yang dapat dijadikan modal pengembangan seperti lumber daya manusia (santri, wali santri, alumni, simpatisan/masyarakat), organisasi (pesantren), sumber daya alam (tanah dan lingkungan pedesaan), modal (dana berputar dari santri dan masyarakat).

\section{Pesantren dan Bentuk Kemandirian Ekonomi}

Kata "kemandirian" berasal dari kata dasar "mandiri" yang mendapat awalan "ke" dan akhiran "an", kemudian membentuk satu kata keadaan atau kata benda. Karena kemandirian berasal dari kata "diri", maka pembahasan mengenai kemandirian tidak bisa lepas dari pembahasan tentang perkembangan diri itu sendiri, yang dalam konsep Carl Rogers di sebut dengan istilah self, karena diri itu merupakan inti dari kemandirian. ${ }^{27}$

Istilah kemandirian menunjukan wujud kepercayaan terhadap kemampuan diri dalam menyelesaikan masalah tanpa bantuan dari orang lain. Individu yang mandiri sebagai individu

27 Desmita, Psikologi Perkembangan Peserta Didik (Bandung: Remaja Rosdakarya, 2014). 185 
yang dapat menyelesaikan masalah-masalah yang dihadapinya, mampu mengambil keputusan sendiri, mempunyai inisiatif dan kreatif, tanpa mengabaikan lingkungan di sekitarnya. Menurut beberapa ahli "kemandirian" menunjukan pada kemampuan psikososial yang mencakup kebebasan bertindak, tidak bergantung dengan kemampuan orang lain, tidak terpengaruh lingkungan, dan bebas mengatur kebutuhanya sendiri. ${ }^{28}$

Kemandirian berdasar pada paradigma yang menyatakan bahwa setiap individu atau kelompok bertanggung jawab atas kehidupannya sendiri. Stein dan Book menyatakan bahwa kemandirian merupakan kemampuan untuk mengarahkan dan mengendalikan diri sendiri dalam berpikir dan bertindak, serta tidak merasa bergantung pada orang lain secara emosional. ${ }^{29}$ Menurut Bathi, kemandirian adalah perilaku yang aktivitasnya diarahkan kepada diri sendiri, tidak banyak mengharapkan bantuan dari orang lain, dan bahkan mencoba memecahkan masalahnya sendiri. 30

Witherington dalam Spencer mengemukakan bahwa perilaku kemandirian ditunjukkan dengan adanya kemampuan untuk mengambil inisiatif, kemampuan mengatasi masalah serta keinginan untuk mengerjakan sesuatu tanpa bantuan orang lain. ${ }^{31}$ Sedangkan Lindzey dan Aronson menyatakan bahwa orang-orang yang mandiri menunjukkan inisiatif, berusaha untuk mengejar prestasi, menunjukkan rasa percaya diri yang besar, secara relatif jarang mencari perlindungan dari orang lain serta mempunyai rasa ingin menonjol. ${ }^{32}$ Mandiri adalah sikap yang mampu mengurus kehidupannya sendiri dan

28 Eti Nurhayati, Psikologi Pendidikan Inovatif (Yogyakarta: Pustaka Pelajar, 2011). 131

29 Steven J. Stein and Howard E. Book, Ledakan EQ, Terjemahan Trinanda Rainy Januarsari Dan Yudhi Murtanto (Bandung: Kaifa, 2000).105

30 Bathi H.K, Educational Psyichology (New Delhi: The Macmillen company or India limited, 1977).28

31 Spencer and Koss, Persperctive in Child Psychology (New York: Mc.Grow Hill Book Company, 1970). 17

32 Lindzey G and Aroson E, The Handbook of Social Psychological (New Delhi: The Macmillan Limited Publishing, 1968).218 
tidak menjadi beban orang lain. Sikap mandiri bukan sikap egois atau hidup sendiri, melainkan sikap bersedia dan mampu membangun kehidupan sendiri dalam rangka kebersamaan.

Kemandirian merupakan identitas diri seorang Muslim yang berlandaskan tauhid yang kokoh, sehingga mampu untuk tampil sebagai khali $>$ fah fi> al-ard\} (divine vicegereny), bahkan harus tampil menjadi shuhada> 'ala $>$ al-na $>$ s, menjadi pilarpilar kebenaran yang kokoh. Maka keyakinannya akan nilai tauhid menyebabkan setiap pribadi Muslim akan memilki semangat jihad sebagai etos kerjanya. Semangat jihad ini melahirkan keinginan untuk memperoleh hasil dan usaha atas karya dan karsa yang dibuahkan dari dirinya sendiri. Kemandirian bagi seorang Muslim adalah lambang perjuangan semangat jihad (fighting spirit) yang sangat mahal harganya.

Menurut Priambodo sebagaimana yang dikutip oleh Djazimah, menyatakan secara konseptual kemandirian ekonomi memilki parameter atau ukuran ukuran tertentu diantaranya: ${ }^{33}$

1. Kemandirian ekonomi seseorang ditandai oleh adanya usaha atau pekerjaan yang dikelola secara ekonomis. Artinya, usaha atau pekerjaan itu berorientasi pada keuntungan.

2. Kemandirian juga berangkat dari rasa percaya diri seseorang dalam melakukan aktivitas ekonomi, seperti usaha dagang, wirausaha dalam bentuk home industri, pengelolaan perusahaan dan lain sebagainya.

3. Kemandirian ekonomi ditandai oleh kegiatan ekonomis yang ditekuni dalam jangka waktu lama sehingga memungkinkan seseorang mempunyai kekuatan secara ekonomis untuk maju dan berkembang.

4. Kemandirian ekonomi juga ditandai oleh sikap berani dari seseorang atau kelompok orang untuk mengambil risiko dalam aktivitas ekonomis, misalnya bermimpi besar dan

33 Siti Djazaimah, "Potensi Ekonomi Pesantren,” Jurnal penelitian agama Vol.1 (2004): 427. 
berusaha keras untuk mewujudkan mimpi-mimpi tersebut, berani meminjam uang sebagai modal usaha dengan perhitungan rasional dan realistis, berani mengambil keputusan bersifat bisnis untuk memprediksi peluangpeluang yang ada.

5. Kemandirian ekonomi juga dilihat dari sikap seseorang yang tidak terikat kebijakan secara ekonomis oleh orang lain.

Chapra menjelaskan bahwa dalam mengaktualisasi kemandirian ekonomi umat dengan sistem ekonomi Islam, dapat dilakukan melalui lima pilar utama, dimana kelima pilar ini merupakan prinsip dasar (kerangka acuan) untuk mensejahterakan umat itu sendiri. Kelima pilar utama tersebut adalah sebagai berikut: ${ }^{34}$ (1) Pembangunan Faktor Manusia; (2) Mengurangi Pemusatan Kekayaan; (3) Restrukturisasi Ekonomi; (4) Restrukturisasi Keuangan; dan (5) Perencanaan Kebijakan Strategis.

Abdul Halim berpendapat kemampuan pemerintah daerah dalam membiyai sendiri kegiatan pemerintahan, pembangunan, dan pelayanan kepada masyarakat yang telah membayar pajak dan retribusi sebagai sumber pendapatan yang di perlukan daerah adalah bentuk kemandirian keuangan daerah. ${ }^{35}$

\section{Kegiatan Perekonomian dan Profil Unit Usaha di Pesantren Mambaus Sholihin}

Pondok Pesantren Mambaus Sholihin dalam menjalankan roda ekonomi di bidang ekonomi diawali keinginan pengasuh untuk mandiri/tanpa mengharapkan bantuan pihak lain, dengan semangat inilah pengasuh mendirkan beberapa usaha untuk mewujudkan kemandirian dan sekaligus untuk memenuhi kebutuhan santri dan

34 Umar Chapra, Islam and Economic Development (Pakistan: Internasional Insitute of Islamic Thought and Research Insitute, 1993).62-100

35 Abdul Halim, Dasar-Dasar Audit Laporan Keuangan (Yogyakarta: UPP STIM YKPN, n.d.).56 
masyarakat sekitar. Usaha awal berupa kedai dan warung kelontong di dalam lingkungan pesantren memenuhi kebutuhan para santri. Diantara kegiatan perekonomian yang berada dalam pesantren Mambaus Sholihin adalah:

Pertama, Koperasi Pondok Pesantren (KOPONTREN). Usaha ini didirikan saat bangsa Indonesia mulai memasuki lembah krisis multidimensi yang terus berlanjut hingga kini. Hanya dengan bermodalkan Rp. 5.000.000,- dan rumah sewaan, Kopontren ini mulai beroperasi dengan menyediakan kebutuhan santri. Namun setapak demi setapak Kopontren Mambaus Sholihin mulai mengalami kemajuan dengan menyediakan kebutuhan-kebutuhan masyarakat sekitar. Pelanggan Kopontren semakin banyak seiring dengan jumlah santri yang setiap tahun semakin banyak.

Setelah enam tahun bergelut dalam bidang bisnis dan perdagangan, kini Kopontren Induk Mambaus Sholihin berhasil mengepakkan sayapnya, dengan dibukanya Kopontren Mambaus Sholihin II yang beroperasi di Desa Betoyo Manyar Gresik sejak tahun 2005.36 Kendala kopontren Mambaus Sholihin adalah kurangnya penguasaan manajemen dari pengurus kopontren, sehingga sampai saat ini kopontren hanya bergerak dalam penjualan kebutuhan santri tanpa bergerak dalam bidang lain. Di samping itu, selalu bertukarnya formasi pengurus kopontren, sehingga membuat manajemen pesantren selalu berubah.

Kedua, Klinik Umum Dar al-Syifa' Sebagai Wahana Pelayanan Kesehatan Bagi Santri Dan Masyarakat. Sebagai salah satu upaya peningkatan kepedulian terhadap masalah kesehatan khususnya bagi santri dan umumnya bagi masyarakat sekitarnya, maka Pondok Pesantren Mambaus Sholihin membangun sebuah sarana peningkatan kesehatan yang diberi nama klinik umum Dar al-Syifa'. Adapun klinik umum ini sendiri berdiri pada 3 November tahun 2002 dan baru diresmikan oleh

36 Dwi Iqbal Firdaus, Wawancara, Gresik, 12 Maret 2018. 
bupati Gresik, Drs. K.H Robbach Ma'shum MM pada tanggal 13 Maret 2004. ${ }^{37}$

Dalam kesehariannya, klinik umum ini beroperasi selama 24 jam dengan dua petugas medis yang cukup handal yakni dr. Elly Sobichah dan dr. Syaiful Arief, yang selalu siap sedia dalam 24 jam. Diharapkan memberikan kontribusi terhadap peningkatan mutu kesehatan santri dan masyarakat sekitar. Adapun bagi santri Mamba'us Sholihin selama masih dalam tahap pengobatan wajar yang tidak memakan biaya besar dan seperti yang telah ditentukan oleh dewan pengelola klinik umum Dar al-Syifa', maka bisa memanfaatkan JPKM (Jaminan Pemeliharaan Kesehatan Santri) yang telah disediakan dalam artian bisa mendapatkan pengobatan secara gratis.

Dalam rangka peningkatan pelayanan, maka dalam menjalankan tugasnya para dokter didampingi oleh beberapa petugas dengan spesifikasi bidang bagi masing-masing individu. Untuk pelayanan bidang administrasi dikerjakan oleh Zulifah dibantu oleh Lilik Faridah. Dan juga untuk membantu dokter guna meningkatkan pelayanan bagi santri dan masyarakat dalam masalah medis telah diangkat beberapa perawat yaitu Maftuchah Amk dan Masruroh Vivianti, Amk serta Mamik Marwati serta seorang bidan, Nyimas Jamaliah Amd.Keb.

Ketiga, Unit Usaha Air Minum (MBS Water). Usaha yang didirikan sejak tahun 2013 ini tergolong unit industri yang sangat potensial, karena di samping memiliki pangsa pasar yang jelas, juga karena mutu dan kualitas produknya mampu bersaing, dan telah menempatkan unit ini menjadi salah satu unit usaha yang diperhitungkan oleh kompetitor dengan prospek yang menjanjikan. ${ }^{38}$ Unit usaha air minum pesantren yang diberi nama MBS Water yang diketuai Saifullahil maslul dibawah pengawasan H. Agus Majdudin dan dibantu oleh dua belas karyawan mempunya empat produk yaitu gelas, botol kecil, botol besar dan galon dan dalam setiap harinya 
memproduksi enam ratus lima puluh gelas, seratus botol dan enam puluh galon.

Keempat, Unit Usaha Home industry. Unit Usaha Home industry menyediakan makanan ringan yang memenuhi standar kesehatan. Dengan menargetkan lima program pokok yaitu: peningkatan omzet usaha, pendirian tempat yang layak untuk produksi, mengkoordinir unit usaha dalam pengadaan makanan ringan khususnya di dalam pondok, memperluas jangkauan pasar, menjaga mutu dan kualitas makanan ringan sesuai standar kesehatan. Unit ini memiliki prospek yang cukup bagus dan pangsa pasar yang menjanjikan, sebab racikan bahan-bahan membuat makanan ringan juga pangsa pasar yang sangat signifikan sebab produk ini sangat digandrungi oleh santri, guru. ${ }^{39}$

Usaha home industry pesantren setiap harinya membuat makanan ringan yang disetorkan di tiap-tiap kantin pesantren, dengan menu yang terjadwal yang selalu mencoba dengan inovasi-inovasi makanan ringan, agar para santri tidak bosan. Disamping itu home industry dalam manajemenya menunjuk satu kordinator dan memilih para santri masa pengabdian ditugaskan dalam menjalankan usaha home industry, sehingga home industry bisa menjadi pelatihan santri dalam menumbuhkan kewirausahaan santri.

Kelima, Unit Home industry. Unit usaha ini didirikan untuk memenuhi kebutuhan santri berupa makanan ringan yang disetorkan ke kantin-kantin yang ada dalam pondok pesantren. Unit Usaha Home industry menyediakan makanan ringan yang memenuhi standar kesehatan. Dengan menargetkan lima program pokok yaitu: peningkatan omzet usaha, pendirian tempat yang layak untuk produksi, mengkoordinir unit usaha dalam pengadaan makanan ringan khususnya di dalam pondok, memperluas jangkauan pasar, menjaga mutu dan kualitas makanan ringan sesuai standar

39 Neng Musyafaah, Wawancara, Gresik, 20 Ferbuari 2018. 
kesehatan. Unit ini memiliki prospek yang cukup bagus dan pangsa pasar yang menjanjikan, sebab racikan bahan-bahan membuat makanan ringan juga pangsa pasar yang sangat signifikan sebab produk ini sangat digandrungi oleh santri, guru dan masyarakat sekitar pondok.

Keenam, Unit Usaha Tahu. Tahu merupakan sumber protein nabati bagi manusia kaya akan protein yang dibutuhkan oleh tubuh manusia. Selain mudah didapat tahu juga bisa dibeli dengan harga terjangkau, dan makanan yang paling digemari bagi orang banyak sehingga usaha ini mempunyai peluang yang sangat besar, disamping sekarang ini banyak inovasi-inovasi makanan yang berbahan dasar tahu. ${ }^{40}$ Usaha tahu ini bermula dari inisiatif pimpinan pesantren guna memenuhi kebutuhan lauk-pauk di dapur umum santri, diketuai oleh saudara miftah dan dibantu oleh empat anggota santri, setiap harinya usaha tahu pesantren Mambaus Sholihin memenuhi kebutuhan pesantren dengan membuat tahu tujuh bak dalam setiap harinya yang didistribusikan pondok putra, pondok putri dan pondok selatan.

Usaha ini tergolong unit industri yang sangat potensial, karena di samping memiliki pangsa pasar yang jelas, juga karena mutu dan kualitas produknya mampu bersaing, dan telah menempatkan unit ini menjadi salah satu unit usaha yang diperhitungkan oleh kompetitor dengan prospek yang menjanjikan. Sejarah mencatat bahwa usaha tahu merupakan produk lokal yang sulit digeser oleh produk asing manapun karena sudah menjadi tradisi.

\section{Kiprah Kiai dan Faktor Kemandirian Ekonomi Pesantren Kiprah Kiai}

Kiprah Kiai Masbuhin Faqih dalam pengelolaan unit-unit usaha pesantren sifatnya tidak langsung. Beliau menunujuk putra-putri Kiai untuk mengatur dan mengawasi semua unit usaha yang ada dalam pesantren. Meskipun tidak menjadi

40 Naser, Wawancara, Gresik, 18 Februari 2018. 
pengelola utama dalam setiap unit usaha, kiai selalu mengawasi setiap kegiatan, termasuk masalah keuangan. Namun Kiai tidak turut campur dalam hal pengelolaan.

Dalam hal ini, Kiai berperan sebagai gagasan untuk pendirian dan cara pengelolaan. Setiap kegiatan harus dilaporkan kepada Kiai. Jika tidak sesuai dengan pemikiran Kiai maka akan ditolak. Dalam rapat Yayasan yang diadakan setiap tahun, Kiai Masbuhin menerima laporan dari setiap unit usaha. Jika ada yang salah, Kiai akan mengevaluasi. Jika ada unit usaha yang ingin membuat ide baru, maka harus dilaporkan dulu kepada Kiai. Sehingga penentu kebijakan unit Usaha adalah Kiai. ${ }^{41}$

Kendati Kiai sudah berusaha sebaik mungkin dalam mengatur unit usaha baik secara lahir maupun batin. Namun tetap saja ada kendala yang tak dapat dihindari. "Kendalanya ada di dalam Sumber Daya Manusia. Peluangnya sebenarnya sangat besar. Misalnya Kopontren seharusnya bisa dikelola sebagaimana minimarket yang bisa memiliki cabang di banyak tempat. Namun karena kendala SDM, apa yang jadi keinginan saya belum bisa terpenuhi. Persoalannya karena tidak ada SDM yang bisa mengelola dengan baik." Kata Kiai Masbuhin.

Kendala SDM ini juga terjadi dalam Unit Usaha MBS Bakery. Karena sampai sekarang belum ada santri yang mumpuni dalam mengelola, maka sampai sekarang MBS Bakery belum berjalan dengan baik. Dari sekian banyak Unit Usaha di pondok pesantren Mambaus Sholihin, menurut Kiai Masbuhin Faqih, MBS Water lah yang paling banyak menghasilkan keuntungan. Sebab permintaan yang terus meningkat baik di kalangan santri maupun alumni. Dalam hal ini, konsumen MBS Water juga banyak dibeli oleh alumni. Harapannya, Kopontren juga bisa demikian. Kopontren bisa berkembang dengan memiliki banyak cabang.

41 Observasi di Pondok Pesantren Mambaus Sholihin 19 Maret 2018. 
Mengenai santri yang bisa ikut terjun mengelola unit usaha, Kiai Masbuhin membuat kebijakan khusus. Yakni, santri yang bisa ikut mengurus unit usaha adalah yang sudah lulus aliyah. Artinya hanya mahasiswa atau yang sudah sarjana yang boleh mengelola unit usaha. Itupun hanya dipilih dari mahasiswa kurang mampu yang biaya bulanannya selama kuliah dan mondok mendapatkan bantuan dari pondok. "Santri yang bisa khidmah, adalah mahasiswa Inkafa dan yang mendapatkan tunjangan." Kata Kiai.

Kiai dalam mengembangkan unit usaha pesantren melakukan berbagai strategi dan terobosan, seperti; pertama, doktrin agama sebagai penyiapan SDM santri. Kedua, memberdayakan alumni yang tergabung dalam Himpunan Alumni Mambaus Sholihin (Himam) untuk menyebar serta memasarkan produk, sebab alumni pesantren Mambaus solihin juga banyak yang menjadi orang terpengaruh di tengah masyarakat, sehingga memudahkan pesantren untuk melebarkan sayap melalui pemberdayaan jejaring alumni. Ketiga, memberikan pelayanan yang memuaskan akan produk yang diperjualbelikan untuk mempertahankan kepercayaan masyarakat. ${ }^{42}$

Dengan kebijakan Kiai dalam mengatur perekonomian pesantren, keuntungan yang didapat dari unit usaha yang ada di dalam pesantren bisa membantu dalam pembangungan pesantren. Baik untuk pesantren pusat maupun cabang. Dari total uang yang dikeluarkan pesantren untuk biaya pembangunan selama setahun, 5-10\% diperoleh dari hasil usaha. Sebab dalam sebulan uang yang dikeluarkan rata-rata RP. 800.000.000.

\section{Faktor Kemandirian Ekonomi Pesantren}

Awal sejarah perjalan ekonomi pesantren secara filosofis memang berangkatnya dari prinsip kemandirian Pondok yang tidak mau menggantungkan kepada pihak lain,

42 Ibid. 
yang sebagaiman termaktub dalam visi pesantren, Alim, Sholeh Kafi. Pengasuh dalam menunjukan kemandirian tersebut, di antaranya dengan membuka unit-unit usaha meski hanya terbatas untuk kalangan internal yang ada dalam lingkungan Pesantren. Langkah awal pengasuh adalah dengan membatasi pengeluaran santri, artinya mengupayakan semua kebutuhan santri disediakan oleh pesantren, sehingga siklus perputaran uang tidak banyak keluar dan pada akhirnya itu mencapai keberhasilan.

Seperti perkataan Kiai pengasuh PP. Darussalam gontor bahwa jika punya santri 1000 (seribu) saja kemudian bisa mengelolanya, maka hasilnya akan bisa membangun gedung baru setiap tahun, sehingga dengan tidak perlu berekspansi keluar pun, kita sudah punya modal sangat kuat untuk bisa mengelola unit usaha di dalam pesantren. ${ }^{43}$ Faktor yang membentuk dan menentukan kemandirian ekonomi adalah terletak pada SDM (sumber daya manusia) dan kepercayaan masyarakat pada unit usaha pesantren yang secara umum memberikan dampak positif, karena dengan itu masyarakat akan memilih bertransaksi dengan unit usaha dibawah naungan pesantren daripada berbelanja ke tempat lain.

Sedangkan Pihak-pihak yang berpengaruh terhadap kemandirian ekonomi pesantren ada dua, pihak dalam dan pihak luar. Pihak yang berpengaruh di dalam, adalah semua komponen pondok yang terlibat dalam pengembangan ekonomi Pesantren meskipun yang lebih banyak yang secara tidak langsung. Sedangkan pihak yang berpengaruh dari luar adalah dukungan dan kepercayaan dari masyarakat. Masyarakat memipunya rasa memiliki yang kuat terhadap pondok pesantren kalau dilihat secara faktual. hal ini terbukti lebih memilihnya masyarakat berbelanja di pondok pesantren dibanding dengan membeli di tempat lain. Maka langkah yang harus dilakukan oleh unit usaha pesantren adalah dengan meningkatkan kualitas produk maupun layanan, sehingga akan

43 Observasi di Pondok Pesantren Mambaus Sholihin 21 Maret 2018.

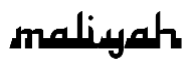


berdampak baik pada tingkat kepuasan yang dirasakan oleh konsumen dalam hal ini adalah masyarakat umum. ${ }^{44}$

Ada beberapa problematika yang dihadapi pesantren Mambaus Sholihin dalam mewujudkan pesantren mandiri secara ekonomi. Pertama, adalah terkait dengan sumber daya manusia (SDM) yang menjadi problem utama sekaligus terbesar. Kedua, adalah problem berkenaan dengan permodalan, di mana unit usaha yang secara finansial lemah akan kesulitan mendapat suntikan modal untuk memperkuat atau mengembangkan unit usaha yang ada. Sehingga dibutuhkan dana segar yang bisa didapatkan dari pihak lain seperti bank syariah, pinjaman alumni, atau pinjam antar-unit usaha agar problematika permodalan dapat teratasi dan tentunya unit usaha akan terangkat kekuatannya.

\section{Peran Kiai pada kemandirian pesantren Mambaus Sholihin}

Berdasarkan pada data dalam pembahasan sebelumnya dapat diketahui bahwa kiprah kiai sebagai pemimpin dalam membentuk kemandirian ekonomi pesantren Mambaus Sholihin diantranya sebagai berikut:

Pertama, fungsi instruksi. Fungsi ini berlangsung dan bersifat komunikasi satu arah. Pemimpin sebagi pengambil keputusan berfungsi memerintahkan pelaksanaanya pada orang-orang yang dipimpin, dan seorang kiai mempunyai andil besar dalam hal ini, seperti memberikan kebijakan-kebijakan demi kemajuan ekonomi pesantren. Kiai selalu memberikan ide dan gagasan terhadap lembaga atau pun biro yang bersangkutan guna turut serta memberikan sumbangsih pemikiran yang kemudian dapat dijalankan oleh para anggota. Sikap seperti ini yang menjadikan para kiai sebagai barometer utama dalam setiap hal program yang akan dilaksanakan.

Kedua, fungsi konsultatif. Komunikasi ini berlangsung dan bersifat dua arah, meskipun pada pelaksanaannya tergantung pada pihak pemimpin, yakni kiai membuka usulan 
dari pihak-pihak terkait, tetapi keputusanya tetap pada kiai. Dalam hal ini kiai berperan sebagai pengambil keputusan (policy maker) baik atas pertimbangannya sendiri, ataupun setelah mempertimbangkan pendapat kelompoknya.

Ketiga, fungsi partisipatif. Fungsi ini tidak sekadar berlangsung dan bersifat dua arah, tetapi juga berwujud pelaksanaan hubungan manusia yang efektif antara pemimpin dengan dan sesama orang yang dipimpin. Dalam fungsi ini pemimpin berusaha mengaktifkan orang-orang yang dipimpinnya, baik dalam pengambilan keputusan maupun pelaksanaannya, ini bisa dilihat dari pertemuan tahunan yang diadakan kiai untuk membahas pelaporan dan program tahunan.

Keempat, fungsi delegatif. Fungsi ini dilaksanakan dengan memberikan pelimpahan wewenang membuat/ menetapkan keputusan, baik melalui persetujuan maupun tanpa persetujuan pemimpin.

Kelima, fungsi pengendalian. Fungsi ini cenderung bersifat komunikasi satu arah, meskipun tidak mustahil untuk dilakukan dengan cara komunikasi dua arah. Fungsi pengendalian bermaksud bahwa kepememimpinan yang sukses/efektif mampu mengatur aktivitas anggotanya secara terarah dan dalam koordinasi yang efektif, dalam hal ini kiai tidak terlibat langsung, tetapi menunjuk salah satu orang kepercayaanya dalam mengawasi usaha pesantren.

Keenam, fungsi teladan. Artinya, seorang kiai dijadikan model perilaku yang dapat diteladani pengikutnya. Ini peran besar yang harus dilakukan oleh kiai, yakni menjadi teladan bagi pengikutnya, baik warga pesantren maupun masyarakat umum secara luas. Keteledanan yang baik menjadi hal urgen yang harus dilakukan, agar pihak lain dapat meniru dan mengikuti jalan kebaikan yang telah dilakukan oleh kiai yang posisinya sebagai pimpinan pesantren.

Gagasan Kiai Masbuhin Faqih dalam kemandirian ekonomi pesantren erat kaitanya dengan filosofi pesantren itu 
sendiri. Filosofi ini dikenal dengan Alim Soleh Kafi. Kafi artinya cukup segala-galanya, baik dalam segi ilmu, ahlaq, dan kemandirian ekonomi. Dari sinilah mulai terpikirkan gagasangagasan membangun unit-unit usaha pesantren untuk mewujudkan kemandirian ekonomi pesantren. Kiprah lain adalah kiai juga sebagai pemberi modal unit usaha pesantren, sekaligus menjaga dan mengawasi dari pelaksanaan kegiatan perekonomian, meskipun terkadang secara tidak langsung tapi menunjuk orang kepercayaanya sehingga memberikan kekuatan permodalan guna mengembangkan unit usaha yang dimiliki pesantren.

\section{Strategi Kiai dalam Membentuk Kemandirian Ekonomi Pondok Pesantren Mambaus Sholihin}

Beberapa langkah yang dianggap kiai sangat efektif untuk mencapai kemandirian ekonomi, yang mana seorang kiai mempunyai langkah-langkah strategis yang bisa mengantarkan kepada tujuan tersebut. di antara langkah kiai untuk mencapai tujuan kemandirian ekonomi sebagai berikut: 45

Pertama adalah faktor koktrin agama. Agama merupakan petunjuk bagi manusia, baik di dalam masalah keduniaan maupun masalah ibadah dengan Tuhan. Dalam segi muamalah (hubungan keduniawian) agama-agama samawi telah mengatur umatnya, baik yang berhubungan antar manusia dalam bidang pemerintahan, hukum, kemasyarakatan, maupun persoalan-persoalan yang berhubungan dengan ekonomi. ${ }^{46}$ Pada bidang ekonomi, para ilmuwan telah mengadakan suatu penelitian secara mendalam hubungan agama dan ekonomi, yang salah satu pokok penelitiannya adalah, adakah kontribusi agama terhadap semangat ekonomi pada masyarakat.

Seperti yang dilakukan oleh Kenneth Boulding, di dalam penelitianya tentang pengaruh agama Kristen protestan

45 Observasi di Pondok Pesantren Mambaus Sholihin 29 Maret 2018

46 Mohammad Nadzir, "Membangun Pemberdayaan Ekonomi Di Pesantren," Jurnal economica Vol.1 ed.1 (n.d.). 
terhadap semangat ekonomi, ia menemukan bahwa pengaruh agama protestan ternyata mempunyai dampak terhadap kehidupan ekonomi dan sejarah, bahkan lebih besar daripada pengaruh agama terhadap pemikiran ekonomi saja. Agama turut mempengaruhi pengambilan keputusan mengenai jenis komoditi yang diproduksi, terbentuknya kelembagaan ekonomi dan tentu juga praktek-praktek atau perilaku ekonomi. $^{47}$

Maka seorang kiai secara tidak langsung memberikan motivasi agama dalam membentuk sebuah kemandirian santri, karena dalam sebuah penelitian yang dilakukan Rizal Muttaqin bahwa hubungan motivasi agama mempunyai hubungan yang sangat erat dalam kemandirian ekonomi, begitu juga yang selalu dilakukan kiai Masbuhin dalam memberikan motivasi agama dalam memebentuk kemandirian, di antaranya dawuh yang sering dikatakan "Tulungen Agamane pengeran pesti awakmu ditolong karo pengeran" (tolonglah agama Tuhanmu pasti Tuhanmu akan menolongmu), sehingga hal ini menumbuhkan kepercaan yang tinggi, dan ini adalah modal yang besar dalam membentuk sebuah kemandirian, begitu juga kemandirian ekonomi.

Kedua adalah pemberdayaan santri. Konsep tentang peran santri dalam pemberdayaan ekonomi sangat menarik dibahas, karena santri yang setiap harinya disibukkan dengan berbagai aktivitas belajar atau mengaji, ternyata juga memiliki aktivitas ekonomi. Pada pesantren tertentu, santri memang dibekali dengan berbagai ketrampilan dan keahlian di bidang ekonomi seperti koperasi, kerajinan dan berdagang. Semua itu dilakukan oleh pihak pesantren sebagai bentuk upaya untuk membekali para santri dengan berbagai skill keahlian atau setidaknya menyiapkan mental dan ketrampilan para santri supaya kelak ketika keluar dari pesantren sudah bisa mandiri. Oleh karena itu wajar jika pesantren berusaha

47 Keneth E Boulding, Beyon Economics, Essay On Society, Relegion Ana Ethics (The University of Michigan, Ann Arbor, 1970).180 
mengembangkan diri dengan melakukan suatu tindakan nyata (da'wah bi al-h\}a>l) pada masyarakat di sekitar pesantren di segala bidang, termasuk di dalamnya pemberdayaan ekonomi. ${ }^{48}$

Ketiga adalah pengorganisasian pesantren. Seseorang atau kelompok membentuk atau memasuki sesuatu kelompok untuk kerjasama tiada lain karena suatu tujuan atau paling tidak dengan membentuk kerjasama agar tujuanya akan terwujud suatu tingkat kepuasan tertentu. Oleh karena itu ada kecenderungan bahwa orang yang berpengaruh dapat mempengaruhi seseorang atau bahkan sekelompok orang. Disinilah seharusnya para pengasuh atau pimpinan pesantren melalui pengaruhnya yang cukup besar dilingkungan intern maupun ekstern menglola kerjasama dalam rangka pengembangan SDM pesantren, sebab mereka menempati kedudukan penting dala kehidupan pesantren. Munculnya kelompok kerjasama atau organisasi, adalah karena setiap orang yang jadi anggotanya merasa tingkat produktivitas, kepuasan kerja, dan kemajuan lebih tinggi, bahkan kebutuhannya relatif terpenuhi jika melakukan kerjasama dibandingkan dengan berusaha sendiri.

\section{Analisis Faktor-Faktor yang Membentuk Kemandirian Ekonomi di Pondok Pesantren Mambaus Sholihin.}

Secara umum ada dua hal yang membentuk kemandirian ekonomi, yakni faktor internal dan faktor eksternal. Faktor internal adalah semua warga pesantren, baik kiai, ustaz, santri, pengurus, manajer dari unit usaha, dan karyawan tentunya. Akan tetapi mereka mempunyai peran yang berbeda-beda, ada yang secara langsung dan ada yang tidak langsung. Sehingga faktor internal ini menjadi kekuatan besar dan sangat perlu untuk terus ditingkatkan, karena dari faktor internal itu sendiri kegiatan perokonomian berawal, bertahap, dan berkembang menjadi lebih besar.

48 Nadzir, “"Membangun Pemberdayaan Ekonomi Di Pesantren.”" 
Faktor eksternal yang dimaksud adalah masyarakat luas sekitar pondok Mambaus Sholihin yang turut serta membentuk kemandirian ekonomi pesantren dengan membeli atau berbelanja di unit usaha yang dimiliki pesantren. Dan ini adalah bentuk partisipasi masyarakat untuk mendukung tercapainya kemandirian ekonomi pesantren. Hal penting lainya adalah pesantren selalu menjaga kualitas layanan dan kepercayaan masyarakat. Artinya, pihak unit usaha pesantren harus terus menjaga kepercayaan tersebut, yang selama ini sudah ada dalam masyarakat. Dan cara yang tepat adalah dengan memberikan layanan yang berkualitas dan juga meningkatkan kualitas produksi, sehingga masyarakat puas dan selalu percaya dengan usaha ekonomi yang ada dalam pesantren.

Siti Djazimah menegaskan bahwa kemandirian ekonomi memiliki indikator atau ukuran tertentu di antaranya: ${ }^{49}$ (1) ditandai oleh adanya usaha atau pekerjaan yang dikelola secara ekonomis; (2) kemandirian juga berangkat dari rasa percaya diri seseorang dalam melakukan aktivitas ekonomi; (3) kemandirian ekonomi ditandai oleh kegiatan ekonomis yang ditekuni dalam jangka waktu lama sehingga memungkinkan seseorang mempunyai kekuatan secara ekonomis untuk maju dan berkembang; (4) kemandirian ekonomi juga ditandai oleh sikap berani dari seseorang atau kelompok orang untuk mengambil risiko dalam aktivitas ekonomis; (5) kemandirian ekonomi juga dilihat dari sikap seseorang yang tidak terikat kebijakan secara ekonomis oleh orang lain; dan (6) memperkuat potensi ekonomi lokal.

Pondok pesantren Mambaus Sholihin dapat dikatakan sudah mencapai kemandirian dalam ekonomi kalau dilihat secara umum karena bentuk kebutuhan pendanaan dapat dipenuhi oleh pesantren itu sendiri tanpa adanya campur tangan dari pihak lain, Kemandirian itu dapat tercapai berkat sumbangsih yang besar dan keuletan dari pihak-pihak pesantren dalam mengelola unit usaha pesantren yang dari

${ }^{49}$ Djazaimah, "Potensi Ekonomi Pesantren.”427 
waktu ke waktu terus mengalami pertumbuhan dan perkembangan.

Melihat hal ini pesantren Mambaus Sholihin bukan tidak mungkin akan terus berinovasi dengan mengembangkan perekonomian yang ada saat ini, dengan menambah unit-unit usaha yang baru, baik dalam bidang sama maupun usaha yang berbeda. Tuntutan dalam memajukan dan mengembangkan perekonomian pesantren merupakan keharusan bagi pesantren agar selalu tumbuh dan berkembang sehingga semakin meningkatkan kemandirian dalam pesantren sehingga tanpa mencari bantuan dari pihak lain.

\section{Penutup}

Pertama, peran dan kiprah KH. Masbuhin Faqih dalam mengupayakan terwujudnya kemandirian ekonomi cukup berhasil. Kiprah beliau dimulai dari menggagas ide, berinvestasi, mengawasi, memotivasi, dan juga berperan sebagai pemberi keputusan di berbagai regulasi yang ada dalam unit usaha pesantren.

Kedua, kemandirian ekonomi yang terjadi di Pondok Pesantren Mambaus Sholihin sejauh ini ditopang oleh pesantren ditopang oleh dua faktor internal dan eksternal. Faktor internal adalah para kiai, ustaz, pengurus pesantren, manager unit usaha, dan karyawan perusahaan. Kesemua komponen bersatu padu membentuk dan menjalankan "roda" ekonomi di pesantren secara baik dan tertib. Adapun faktor eksternal adalah masyarakat sekitar pondok Pesantren Mambaus Sholihin yang turut berkontribusi membeli barangbarang yang dijual di unit-unit usaha milik pesantren dan alumni yang juga mendistribusikan barang-barang yang dijual di unit-unit usaha pesantren. Mereka juga bersedia menjalin kerjasama bisnis dengan Pondok Pesantren sehingga saling memberi keuntungan bagi keduanya.

\section{Daftar Pustaka}

A'la, Abd. Pembaruan Pesantren. Yogyakarta: Pustaka Pesantren, 2006. 
Arifin, H.M. Kapita Selekta Pendidikan: Islam Dan Umum. Jakarta: Bumi Aksara, 1995.

Arifin, Imron. Kepemimpinan Kyai: Kasus Pondok Pesantren Tebuireng. Malang: Kalimasada Press, 2003.

Barter, Shane Joshua. "Ulama, the State, and War." Contemporary Islam Vol. 5, No (2011): 20-26.

Boulding, Keneth E. Beyon Economics, Essay On Society, Relegion Ana Ethics. The University of Michigan, Ann Arbor, 1970.

Chapra, Umar. Islam and Economic Development. Pakistan: Internasional Insitute of Islamic Thought and Research Insitute, 1993.

Desmita. Psikologi Perkembangan Peserta Didik. Bandung: Remaja Rosdakarya, 2014.

Dhofier, Zamakhsyari. Tradisi Pesantren: Studi Tentang Pandangan Hidup Kyai. Jakarta: LP3ES, 1982.

Djazaimah, Siti. "Potensi Ekonomi Pesantren." Jurnal penelitian agama Vol.1 (2004): 427.

G, Lindzey, and Aroson E. The Handbook of Social Psychological. New Delhi: The Macmillan Limited Publishing, 1968.

H.K, Bathi. Educational Psyichology. New Delhi: The Macmillen company or India limited, 1977.

Halim, Abdul. Dasar-Dasar Audit Laporan Keuangan. Yogyakarta: UPP STIM YKPN, n.d.

Hamzah, Siti Nur Aini. "Manajemen Pondok Pesantren Mengembangkan Kewirausahaan Agrobisnis: Studi MultiKasus Di Pondok Pesantren Mukmin Mandiri Sidoarjo Dan Pondok Pesantren Nurul Karomah Pamekasan Madura." Tesis Universitas Islam Negeri Maulana Malik Ibrahim Malang, 2015.

Holis, Moh. "Pesantren Dan Pengembangan Perekonomian Di Pondok Pesantren Miftahul Ulum Panyepen, Palengaan, Pamekasan, Madura." Tesis Universitas Islam Negeri 
Sunan Ampel Surabaya, 2008.

Karni, A.S. Etos Studi Kaum Santri: Wajah Baru Pendidikan Islam. Bandung: Mizan, 2009.

Mastuhu. Dinamika Sistem Pendidikan Pesantren: Suatu Kajian Tentang Unsur Dan Nilai Pendidikan Pesantren. Jakarta: INIS, 1994.

Nadzir, Mohammad. "Membangun Pemberdayaan Ekonomi Di Pesantren.'” Jurnal economica Vol.1 ed.1 (n.d.).

Nasir, M. Ridwan. Mencari Tipologi Format Pendidikan Ideal. Yogyakarta: Pustaka Pelajar, 2005.

Nurhayati, Eti. Psikologi Pendidikan Inovatif. Yogyakarta: Pustaka Pelajar, 2011.

Solichin, Mohammad Muchlis. "Kemandirian Pesantren Di Era Reformasi." Nuansa Vol. 9 No. (n.d.).

Spencer, and Koss. Persperctive in Child Psychology. New York: Mc.Grow Hill Book Company, 1970.

Stein, Steven J., and Howard E. Book. Ledakan EQ, Terjemahan Trinanda Rainy Januarsari Dan Yudhi Murtanto. Bandung: Kaifa, 2000.

Tim Pusat Bahasa Departemen Pendidikan Nasional. Kamus Besar Bahasa Indonesia. Jakarta: Gramedia Pustaka Utama, 2008.

Ziemik, Manfred. Pesantren Dalam Perubahan Sosial, Terj. Butche B Soendjoyo. Jakarta: P3M, 1986.

Masbuhin Faqih (Pengasuh Pondok Pesantren Mambaus Sholihin), Wawancara, Gresik 27 Februari 2018.

Naser, Wawancara, Gresik, 18 Februari 2018.

Neng Musyafaah, Wawancara, Gresik, 20 Ferbuari 2018.

Maslul, Wawancara, Gresik, 29 April 2018.

Laila, Wawancara, Gresik, 20 Januari 2018.

Dwi Iqbal Firdaus, Wawancara, Gresik, 12 Maret 2018. 